\title{
Boom and Bust: Economic Voting in Ireland
}

\author{
THERESA REIDY \\ University College Cork
}

JANE SUITER

Dublin City University

MICHAEL BREEN

Dublin City University

\begin{abstract}
The global financial crisis and economic collapse in countries across the world presents new challenges for economic voting models. While there is a consensus that economic voting exists, even the most ardent supporters will agree that it is a variable force and can only explain a portion of voting behaviour (Lewis-Beck 2007). However, when changes in economic circumstances are life altering, the impact is likely to be far greater. This paper explores the asymmetry effects of boom and bust economics on voting patterns at Irish national elections from $2002-2011$, a period which contains three elections with the most recent in 2011 being the third most volatile in European post-war history (Mair 2012). Drawing on the Stegmaier and Lewis-Beck (2011) framework, the paper investigates asymmetric economic voting as a force at routine and crisis elections. Ireland presents a fascinating case study in the examination of economic voting in times of crisis. Indeed, the scale of the political change in Ireland since the economic crisis is at the extreme end of the spectrum of what has previously been captured as economic voting. We find that economic shocks matter a great deal, Irish voters like their counterparts elsewhere are economic voters and this was never as clear as when the economy collapsed in 2011.
\end{abstract}


Keywords: economic voting; Ireland; unemployment; financial crisis

\section{Introduction}

Voters at elections in the Republic of Ireland engage in economic voting but like voters in many other jurisdictions, the extent of the economic vote varies across time. This paper considers economic voting at elections conducted in very different economic environments. The study covers three elections which span the boom and bust in the Irish economy. As such, the paper provides an opportunity to investigate whether economic crises can amplify economic voting. Generally, economic voting is a relatively small force which is significant because it moves voters in one direction; a positive economy will encourage voters to support the incumbent government while the converse is also true. Indeed, some work has suggested that voters are harsher in an economic downturn and more likely to punish the incumbent. Consequently, economic voting can be a decisive force at elections putting parties in and out of government.

The 2011 general election in Ireland was the third most volatile in Western Europe since 1945 and the transformation of the political landscape is attributed to the fallout from the financial and economic crisis. Ireland was one of the first countries to enter recession and the economic crisis has been deep and protracted. The Irish party system can be seen as lying outside the dominant explanatory frameworks used in many European systems but voting behaviour displays evidence of convergence on European norms; partisan de-alignment, leader effects, and economic voting are all in evidence. This paper employs economic voting 
to explore election outcomes at the boom elections of 2002 and 2007 as well as providing a test of economic voting in the midst of economic turmoil and ultimately an EU/IMF bailout.

\section{Literature}

The economic voting literature is united by a fundamental question: do voters evaluate governments on their economic management and if yes, how? Within this broad parameter, a variety of questions have been examined ranging from national to personal economic conditions, how far back voters evaluate; myopic or long range, is there clarity of responsibility within the political system, which level of government is accountable, and are parties within government treated differently. The most persuasive evidence has been uncovered in traditional economic voting models which hypothesise that incumbent governments do better at the polls when the economy is performing well and that voters are generally retrospective. These retrospective models focus on the extent to which voters hold the government to account for past performance. Drawing on V.O. Key's argument that voters attribute responsibility for current economic performance to the government of the day, successive iterations of economic voting models have assessed this relationship (Fiorina 1978; Peffley 1984; Kiewiet and Rivers 1984; Lewis-Beck and Paldam 2000; Nadeau and Lewis-Beck 2000). In a special volume of Electoral Studies (2000: 117), Nadeau and LewisBeck collate the evidence from the thirteen papers in the edition and conclude that retrospective economic voting models continue to outperform prospective models. The global economic crisis has presented new challenges for retrospective models as they are now being invoked to explain electoral swings against a backdrop of rapidly deteriorating economic conditions (Anderson and Hecht 2012). 
With persuasive and extensive evidence to support the retrospective economic voting theory, the field of research diversified into questions of what conditions the economic vote i.e., why does it vary across time and space. Powell and Whitten (1993) in a cross national study demonstrated that responsibility for economic decision making, the ideological image of the government and its electoral base all condition the economic vote. In an extension of this work Duch and Stevenson (2008) argued that economic voting is a conditional law rather than a universal one. Their results confirmed strong economic voting patterns and they identified three sets of conditional factors which are critical to understanding variations in economic voting across countries and time; political control of the economy, concentration and distribution of policy making responsibility over parties and the pattern of contention among parties for future decision making. In an important refinement to the clarity argument, they hypothesise that in countries with "perennial governing parties", the economic vote is weaker. This contention is borne out in their empirical analysis for Belgium, the Netherlands and Italy (2008: 345). Brug et al (2007) also address voters' ability to identify the source of responsibility for economic decision making. While coalitions are conceived as posing a particular challenge because economic decision making may be shared across a number of parties, they argue that the focus should be on the party occupying the post of prime minister and the department of finance. They identify these as important shortcuts available to voters for attributing political responsibility for economic performance. Ireland provides a clear test of the Duch and Stevenson model, in that there was a dominant party of government, high clarity of responsibility conditions and in line with Brug et al, a single party with direct control of economic policy making for fourteen years, albeit within coalition and minority governments. The 2002 and 2007 elections are classified as routine and provide a "normal" 
test of this hypothesis while the 2011 election offers the opportunity to consider whether economic crisis can overcome low level political competition.

The economic voting literature on Ireland is relatively slim. A small number of studies have produced some evidence of a moderate, yet variable retrospective economic vote (Marsh and Tilly 2010; Harrison and Marsh 1998; Borooah and Borooah 1990). The first was by Borooah and Borooah (1990) who found that there was a strong relationship between government popularity and the performance of the national economy from 1974-1987. Unemployment was the most important economic variable identified in this study. A subsequent replication study by Harrison and Marsh (1998) also recorded significant economic voting in Ireland over an extended time period. Both of these studies covered elections which took place against the backdrop of economic crisis, particularly elections in the early 1980s. This work was updated by Marsh et al (2008) which again supported the existence of an economic vote while Marsh and Tilly (2010) later revisited this territory and found it was variable; favoured parties are not blamed for policy failures and less favoured ones are not credited with policy success. More recently, the evidence is that during the period of boom from 2002 to 2007 the economic vote was crowded out by quality of life issues (Marsh et al 2008, and Marsh and Tilly 2010). As such, the studies provide evidence of a positive economic vote. However, it would appear that the economic vote was stronger during recession with voters preferring to punish than reward, with other issues coming to the fore during boom times. The economic collapse offers an opportunity to revisit the economic vote in a time of crisis. There is a limited crisis literature focussing on periods as varied as the 1930s in the US to the 1980s in Ireland to Hungary in the 2000s (Achen and Bartels 2005, Stegmaier and Lewis-Beck 2011). 
Achen and Bartels (2005) explored the impact of the Great Depression on voting behaviour in the 1930s. For the US, they argue that voting patterns can be understood most accurately through the use of retrospective economic voting models, arguing that the political realignment which took place in the 1930s was a consequence of persistent economic voting rather than an ideological shift. Extending this analysis to a number of other countries in the 1930s (including Ireland and Sweden), they hypothesise that economic voting was a major factor in elections in the 1930s was supported. Departing from the nationalist narrative, they argue that economic voting was a component of the growth in support for Fianna Fáil in the 1930s, as the incumbent Cumann na nGaedheal government was punished for poor economic performance arising from the 1929 Wall Street Crash and the ensuing global depression. They conclude that in times of crisis, a strong economic vote can have long lasting impacts in the form of a re-alignment of the party system.

The impact of the recent crisis on election outcomes is only starting to become clear as elections occur. Some early evidence on the impact of the crisis has been provided by Marsh and Mikhaylov (2012), Stegmaier and Lewis-Beck (2011) and Anderson and Hecht (2011). One of the more plausible explanations for the asymmetric reaction of voters to economic crisis lies in the attention that voters pay to recession rather than boom. The attribution of responsibility literature has also shown that voters are more adept at punishment than reward (Kramer 1971, Erikson 1990). In addition, voters with a negative perception of economic performance are more likely to vote (Arceneaux 2003). Furthermore Soroka (2006) has shown that there are asymmetric effects among voters to economic news. Negative information is demonstrated to have a more significant impact on voters' attitudes. As a consequence, a strong negative economic vote would be expected in Ireland in 2011. The 
enormous scale of the economic crisis in Ireland from 2008, a rapid rise in unemployment and the incessant media coverage of the collapse allows us to postulate that voters were conscious of the crisis and that it was a factor in their decision making at the 2011 election. In addition, we know that knowledge matters, and voters with higher levels of knowledge are more likely to punish the government (Bartels 1996; Tillman 2011). Specifically, Tillman demonstrated that UK voters with higher levels of political knowledge were more likely to attribute blame for the financial crisis to the Labour Government.

If voters react more decisively to hard times, it is instructive to know which issues in particular, are the focus of most attention. Perceptions of national economic performance are important for voters and unemployment emerges as a critical litmus test for governments in a range of studies of economic voting (Lewis-Beck and Mitchell 1990; Nannestad and Paldam 1997; Sanders 1999; Bengtsson 2004). Evidence here has been variable, for example Nannestad and Paldam (1997) found high levels of voter ignorance among Danish voters, a subsequent study by Sanders (1999) indicated that although UK voters only have limited economic knowledge, their perceptions of economic performance were reasonably attuned to reality. Nannestad and Paldam (2000) demonstrated that more than half of the Danish voters studied had reasonably accurate knowledge about unemployment figures but few had realistic perceptions of inflation and they knew even less about the overall budget balance.

There are a number of clear messages which can be drawn from the literature. A wide variety of political and institutional factors can condition the economic vote. The evidence is strongest for the retrospective economic voter. Furthermore, voters are more inclined towards 
punishment in times of poor economic performance than reward in good times and they are willing to turn against a government which they had previously trusted to have economic competence. While there are questions about voters' knowledge levels, unemployment resonates strongly with voters and it is this economic variable which is most clearly understood by them. Finally, negative information matters more than positive information. Consequently, we hypothesise that a small economic vote should be evident at Irish elections in 2002 and 2007, when the economy was growing strongly, and that the scale of the macroeconomic crisis, but particularly the employment collapse, should contribute to a significant and large punishment economic vote in 2011. Furthermore, we argue that, although the literature argues that political and institutional factors may condition and constrain the economic vote in normal times, these factors are overwhelmed in the face of the 2008 economic collapse in Ireland. The final element of the argument is that, in times of deep economic crisis, we will expect economic voting to be closer to a universal law and less conditional, with much larger impacts evident.

\section{Boom and Bust in Ireland}

The Irish economy became the subject of international attention in the late 1990s arising from a dramatic surge in economic growth and a particular success in attracting foreign multinational investment into the country. Ireland experienced a remarkable reversal of fortune and the foundations for what became known as the 'good boom' and the 'bad boom' were set. The 'good boom' was marked by a period of export-led growth with GDP rates in excess of 5 per cent and is often known as the Celtic Tiger. The 'bad boom' started to evolve from 2002 and refers to the period of domestic construction-led growth, as construction began to account for 10 per cent of GDP. The global financial crisis collapsed the Irish 8 
banking system, already imperilled by a domestic property mania (discussed in Breen 2012). Ireland was the first country officially to enter recession and growth rates remained in negative territory in 2010, when Ireland accessed a joint EU and IMF package of financial support.

Economic growth matters in Ireland, as elsewhere, but a peculiar historical experience of high unemployment and emigration have combined to elevate public sensitivity to unemployment which is the most salient macroeconomic variable found in previous studies of economic voting. While employment levels rose to unprecedented levels during the boom years, the crisis resulted in a catastrophic collapse. The unemployment rate was just below 15 per cent when the election was called in 2011. It had increased from 4.5 per cent in just two years. Figure 1 provides an overview of the scale of the unemployment volte face in just twenty years.

Figure 1 about here please

Ireland had a dominant party system dating from the 1930s. Party attachment is low by international standards and Marsh (2006) has described the party system as having weak foundations. While ideology has had a limited role in driving electoral outcomes, in recent years, a reputation for competent economic management emerged as the mainstay of support for the dominant party, Fianna Fáil. The party acquired a reputation for competence at economic governance during their 1987-89 period in office and this is identified as a contributing factor to their success at elections from 1997-2007 (Marsh et al 2008; Marsh and 9 
Mikhaylov 2012). Consequently, the economic crisis in 2008 represented a major threat to the support base of Fianna Fáil, in that the party's reputation for economic management disintegrated. The election campaign was dominated by economic issues, unemployment, the terms of the financial bailout and management of the public finances (O'Leary 2012). Sanders (1996) in a paper on election forecasting considered the possible election impacts of the decline in the UK Conservative Party's reputation for competant economic management after Black Wednesday, when the Conservatives saw their support levels drop from 43 per cent to 29 per cent in opinion polls over just one month in 1992. Sanders concluded that if the party did not regain its reputation, it was unlikely to win the 1997 election. The reputational damage of the economic crisis in Ireland for Fianna Fáil appears to have been much more severe and its share of the vote plummeted below 20 per cent in the 2011 election, its lowest vote ever. Mair (in Gallagher and Marsh 2012) has demonstrated that the 2011 general election in Ireland was the third most volatile in Western Europe since 1945.

\section{Hypotheses and Model}

Following the approach used in economic voting we explain FF popularity with sequential additions of individual variables.

The general model is as follows:

$$
\text { Incumbent Vote }=\mathrm{f}(\text { Retrospective Evaluations, Economics })
$$

This paper tests two central hypotheses. Hypothesis one considers the retrospective economic voting relationship. This hypothesis is drawn from a general retrospective macroeconomic voting model. Brug et al (2007) demonstrate that retrospective voting is more prevalent in high clarity countries and Ireland falls into this classification, having had 10 
the same party in power, through a variety of different coalitions for the duration of this study. In addition, the main economic ministry remained with the Fianna Fáil party for the full period. The independent variable of interest was coded from the following survey question:

Thinking back over the last XXX years - the lifetime of the XXXXX government would you say that the ECONOMY in Ireland over that period of time got a lot better; a little better; stayed the same; got a little worse; or got a lot worse?

The second hypothesis employs macroeconomic objective variables, however because of strong multicollinearity and little variation across years it is not possible to utilise more than one objective macro variable at a time. For obvious reasons (and also because on testing it proved the most significant) we have chosen the unemployment rate. In other words we are hypothesising that changes in the unemployment rate will lead directly to changes in vote intention.

\section{Data and Method}

This paper utilises the 2002 to 2007 Irish National Election Study, a five wave panel study extracting the data from the general election years of 2002 and 2007 and appending the more recent election study in 2011, utilising the three years as a cross sectional database. Variables which are common to both strands are renamed and recoded for consistency to allow the researcher to view changes in overall attitudes over time. Thus the dataset is, in effect, a time series for three years 2002, 2007 and 2011. However, we are not able to take full advantage of this data structure by tracking changes among specified individuals over time because the 2011 survey questioned a fresh sample of respondents. 
The dependent variable tested in this paper is recalled vote, as all election studies were taken within a short period of a national election. This obviates the necessity for predicting vote from vote intention. As is standard in economic voting models, this is a dummy variable for government and opposition. This has been found to be problematic in many multi party systems given that coalition government affects the ability of voters to clearly identify a party's contribution to policy outcomes. In many countries, coalition government on occasion allows parties to blame each other and obfuscate responsibility, making it difficult for voters to discern who is actually to blame for political and economic outcomes (Anderson, 1995a, b, Anderson and Hecht 2012) However, in Ireland the governing party Fianna Fáil was dominant over all periods with voters readily able to attribute responsibility. The party has also held the central finance portfolio at all times when it was in government.

The independent variables, which may account for the collapse in the dominant party vote share over time, measure both the routine and the crisis. In general vote function models, from the US to the UK, France and Hungary there are two separate categories for independent economic variables (vigorously tested in France and the United Kingdom, (Lewis-Beck and Stegmaier, 2011; Lewis-Beck and Stegmaier, 2000, 184-188). The first concerns objective macroeconomic indicators, such as unemployment, inflation, or growth (for example, Norpoth 1985). The second concerns subjective indicators, such as subjective indicators of attributions and evaluations pertaining to economic and political performance (See, for example, Marsh and Tilly 2010; Anderson and Hecht 2012). This paper utilises subjective sentiments available from election studies as well as an objective measure of the unemployment rate (survey based ratio of the number of persons unemployed to the number 
of persons in the work force, Central Statistics Office). The subjective measure is a sociotropic retrospective evaluation that asks the individual how they view the performance of the economy over the last year. In terms of the objective indicators, the lack of variation means that we can only run one marco variable in any single estimation. This of course severely hinders its explanatory power but, nonetheless, we think it is worth doing for exploratory purposes.

For control, we also include standard measures of partisanship, information and vote, namely education, income and age. In order to allow for error at this macro level, this paper employs a standard multi-level fixed effect model. The objective macro variables are fixed as are the individual subjective variables. Thus, we argue that the only random effect would be the intercept at individual level, which will be partly explained by the macro level fixed effects and will allow for any unexplored variation between survey years.

\section{Descriptive results}

Before delving into the detailed econometric analysis, it is worth visually examining the data in order to observe the broad patterns that exist. As discussed above, we argue that economic voting is asymmetric and that voters are disproportionate in their responses to punishment and to reward. In Figure 2, we can see that economic voting looks to have been in existence to varying extents in the last three Irish general elections in 2002, 2007 and 2011. In all three cases we see that government supporters are more positive about economic performance over the previous five years than opposition supporters. We can also see that these patterns were asymmetric and more extreme in 2011 with very few voters voting for the Government who 
believed the economy had gotten worse. The difficulty of course for the Government was that most people were now in most negative category: very few voters believed the economy had improved.

Figure 2 about here please

We first turn our attention to the extent of economic voting in each of the last three elections. If we examine Table 1, which includes a basic model of economic voting, we can see that there is evidence, as expected, that retrospective evaluations of the economy mattered in both 2002 and in 2011 but not in 2007. A plausible interpretation for the lack of economic voting in 2007 is that as the economy was turning down, Fianna Fáil was trading on its reputation for economic competence to get the state out of the economic difficulties rather than in any sense being rewarded for a well-run booming economy; however, we cannot be certain because the 2007 model does not pass conventional tests of significance.

The coefficients in Table 1 represent a change in the log odds of voting for the government for a one unit increase in the independent variable, holding other variables constant. All of the variables have been placed on a common scale (0-1) to facilitate comparison. Our main variable of interest - evaluation - has consistently the largest impact on voting behaviour, following closely by partisanship and education. An increase of one unit from the best to the worst evaluation of the economy reduces the log odds of voting for the government by 1.47 in 2002, 2.88 in 2011 and 1.07 for all three elections. These findings suggest that while economic voting matters at routine elections it is even more important at crisis elections. By 
contrast, neither income nor age is a statistically significant predictor of the vote in any time period. We now proceed to interpret our main finding using a more intuitive approach: the change in the predicted probability of voting for the incumbent.

Table 1 about here please

Figure 3 illustrates the marginal effect of retrospective evaluations on voting for the government, holding other variables constant at mean values. We know that these calculations are unrealistic in that the demographic and attitudinal profiles of party supporters do vary in reality; but nonetheless we considered this to be an interesting exercise. The first panel illustrates the impact of evaluations during the 2002 election. It shows that a change from the best to the worst evaluation reduces the probability of voting for the government by .35 , holding other variables constant at mean values. Moreover, the confidence intervals suggest that our estimates of mid-range evaluations ("Little Better" and "Same" categories) are the most precise, while the confidence intervals of our estimates of very negative assessments overlap somewhat. The second panel illustrates the impact of evaluations during the 2007 election. The confidence intervals show that the effect of evaluation is not significantly different from zero. By contrast, the panel for the 2011 election shows that evaluations have a substantial effect on voting behaviour. It shows that a change from the best to the worst evaluation reduces the probability of voting for the government by .59 , a 68 per cent increase in economic voting over the 2002 estimate. The confidence intervals in the 2011 panel suggest that our estimates for individuals who hold negative views (in the "Little Worse" and "Lot Worse" categories) are very precise, at least compared to our other estimates. However, we're less confident about our point estimates for more positive categories, as the confidence intervals overlap considerably. The fourth panel illustrates the 15 
impact of evaluation on voting when one pools the data from all three elections. This panel suggests that a move from the best to the worst evaluation reduces the probability of voting for government by .25 . The confidence intervals suggest that our estimates are more precise, especially for respondents in the middle of the distribution, reflecting the efficiency gains from the larger sample size.

Figure 3 about here please

Table 2 shows results for the same estimation but with the macro variable of unemployment being included. It is statistically significant and associated with a reduction in government support. Due to issues with multicollinearity, the dummy variable for 2011 drops from our fixed effects specification. As a consequence, we present additional estimates from pooled observations and random effects. The substantive effect of a change in the macro rate of unemployment is larger than any other variable, including individuals' evaluations of the economy. A move to the lowest to the highest level of unemployment reduces the probability of supporting the government by .37 , whereas retrospective evaluations in the same model predict a .23 reduction.

Table 2 about here please

We also run a number of simulations for 2011 as reported in Table 3 where we can see that that under most scenarios the Government parties were likely to do badly. The exception is if all voters had positive evaluations of the economy (a very unlikely scenario given the 
economic collapse) the Government would have had a far larger share of the vote (50 per cent). However, the retrospective evaluation of the economy does appear to do the heavy lifting. If all had a negative evaluation of the economy the Government's vote share would have amounted to just 8 per cent. This again underlines the dominance of the retrospective evaluation variable.

Table 3 about here

\section{Conclusions}

Support for the government in Ireland can be broadly explained with a straightforward model of economic responsibility, accounting for much of the variation in vote intention. It appears that economic shocks matter a great deal, Irish voters like their counterparts elsewhere are economic voters and this was never as clear as when the economy collapsed in 2011. Consistent with the literature discussed, the retrospective evaluation variable is significant at the 2011 election. Voters look back especially in times of economic crisis. Overall the standard reward punishment model for understanding the vote stands up well in Ireland, both at times of routine but even more so in times of crisis.

Interestingly, it is clear that negative economic performance has a far greater impact on support levels for parties. The scale of the desertion of Fianna Fáil by voters in 2011 far exceeds any reward which the party accrued in 2002 when the economy was booming and had been given the Celtic Tiger epitaph. The reward for positive performance is limited and might be best seen as inertia. This point goes someway to explaining the long period in 17 
government which Fianna Fáil experienced from 1997 - 2011. It coincided with a decade of economic growth and retrospective voters stayed with the party in power until the economic crisis, reinforcing arguments that reputation for good economic governance can aid a party in power. Conversely, governing through an economic crisis may have the effect of overwhelming existing levels of partisanship. The Irish party system has had weak levels of party attachment for some time which may have made Fianna Fáil more vulnerable to loss of support in a crisis.

Unemployment is the most powerful macroeconomic factor at Irish elections. The surge in unemployment from 2008 drove partisans away from Fianna Fáil in large numbers. However, unemployment mattered at all elections and those uncertain about their employment prospects were more likely to vote against the government, although these were relatively small groups at the 2002 and 2007 elections. The evidence reported is consistent with the long standing salience of unemployment in Irish politics.

Overall, this work demonstrates that economic voting models work well in explaining patterns at Irish elections, both routine and crisis. The economic crisis brought about the collapse of the dominant party of Irish politics for nearly a century. The party continues to struggle more than a year after its Waterloo. More than anything else, the Irish example shows that voters attribute responsibility for an economic crisis to the incumbent government. The Irish political system may turn out to be one of the first to experience the consequences of what has been termed the Great Recession. While economic voting has long been considered a small but consistent force at elections, this paper demonstrates that in an 
economic crisis, economic voting can become a powerful and transformative force in a political system. It may be a predictor of widespread political change ahead in many countries which have been heavily impacted by the economic crisis.

\section{References}

Achen, Chris, and Larry Bartels (2005). "Partisan Hearts and Gall Bladders, Retrospection and Realignment in the Wake of the Great Depression", Paper presented at the annual conference of MPSA, Chicago.

Albright, J.J., and Dani Marinova (2010). "Estimating Multilevel Models using SPSS, Stata, Sas and R". http://www.indiana.edu/ statmath/stat/all/hlm/hlm.pdf

Anderson, Christopher, and Christopher Wlezien (1997). "The Economics of Politics in Comparative Perspective Revisited: An Introduction", Political Behavior 19:1, 1--5.

Anderson, Christopher, Silvia Mendes, Yuliya V., Verdova, and Kim, Haklin (2004) "Endogenous economic voting: evidence from the 1997 British election", Electoral Studies 23:4, 683--708.

Anderson, Christopher and J.D. Hecht (2012). "Voting when the economy goes bad, everybody is in charge, and no one is to blame: The case of the 2009 German election”, Electoral Studies, 31:1, 5--19.

Arceneaux, Kevin (2003). "The Conditional Impact of Blame Attribution on the Relationship Between Economic Adversity and Turnout”, Political Research Quarterly, 56:1, 67 -75. 
Bartels, Larry M (1996). "Uninformed Votes: Information Effects in Presidential Elections", American Journal of Political Science, 40:1, 194--230.

Bengtsson, Asa (2004). "Economic voting: The effect of political context, volatility and turnout on voters' assignment of responsibility", European Journal of Political Research, 43, 749--767.

Borooah, Vani and Vidya Borooah (1990). "Economic performance and political popularity in the Republic of Ireland", Public Choice 67:1, 65--79.

Breen, Michael (2012). "IMF Surveillance of Ireland during the Celtic Tiger", Irish Political Studies 27:3, 431--439.

Dorussen, Han and Michael Taylor (2002). Economic Voting. Routledge: London and New York.

Duch, Ray and Randolph Stevenson (2008). The Economic Vote: How political and economic institutions condition election results. Cambridge: Cambridge University Press.

Erikson, Robert (1990). "Economic Conditions and the Congressional Vote: A Review of the Macrolevel Evidence”, American Journal of Political Science, 34, 373--399.

Erikson, Robert S., MacKuen, Michael .B., and James A. Stimson (2000). "Bankers or Peasants Revisited, Economic Expectations and Presidential Approval". Electoral Studies, 19: 2-3, 295--312.

Evans, Geoffrey (2000). "The Continued Significance of Class Voting”, Annual Review of Political Science 3: 1, 401--417.

Evans, Geoffrey and Robert Andersen (2006). "The Political Conditioning of Economic Perceptions", Journal of Politics, 68:1, 194--207. 
Fiorina, Morris P. (1978). "Economic Retrospective Voting in National Elections: A MicroAnalysis", American Journal of Political Science 22:2, 426--443.

Fiorina, Morris P. (1981). Retrospective Voting in American Elections. New Haven: Yale University Press.

Gallagher, Michael and Micahel Marsh (2008). How Ireland Voted 2007: the full story of Ireland's general election. Dublin: Palgrave Macmillan

Harrison, Michael J. and Michael Marsh (1998). “A Re-examination of an Irish Popularity Function”, Public Choice 94:3, 367--383.

Hibbs, Douglas A. (1977). "Political Parties and Macroeconomic Policy", American Political Science Review 71, 1467--1497.

Kiewet, D. Roderick and Donald Rivers (1984). "A Retrospective on Retrospective Economic Voting”, Political Behavior 6:4, 369--393.

Kinder, Donald and D. Roderick Kiewit, R. (1979). "Economic Discontent and Political Behavior: The role of Personal grievances and collective judgment in congressional voting", American Journal of Political Science, 23:3, 495--527.

Kramer, Gerald H. (1971). "Short-Term Fluctuations in US Voting Behaviour 1896-1964", American Political Science Review 71, 131--143.

Lewis-Beck, Michael S. (1988). Economics and Elections, The Major Western Democracies. Ann Arbor: University of Michigan Press.

Lewis-Beck, Michael S. and Glenn Mitchell (1990). "Transnational Models of Economic Voting: Tests from a Western European Pool", Revisita del Instituto de Estudios Economicos 4, 65--81. 
Lewis-Beck, Michael S. (1995). Data analysis: An introduction. USA: Sage.

Lewis-Beck, Michael S. and Richard Nadeau (2000). "French Electoral Institutions and the Economic Vote”, Electoral Studies 19:2-3, 171--182.

Lewis-Beck, Michael S. and Martin Paldam (2000). "Economic Voting: an introduction", Electoral Studies 19:2-3, 113--121.

Lewis-Beck, M.S., Stegmaier, M., 2000. Economic Determinants of Electoral Outcomes. Annual Review of Political Science, 3, 183 - 219.

Lewis-Beck, Michael S. and Mary Stegmaier (2007). "Economic Models of Voting" In: Dalton, R., Klingemann, H.D., (Eds.), The Oxford Handbook of Political Behaviour (pp.518-527). Oxford: Oxford University Press.

Lewis-Beck, Michael S., Richard Nadeau and Angelo Elias (2008). "Economics, Party and the Vote: Causality Issues and Panel Data”, American Journal of Political Science $52: 1,84--95$.

Lewis-Beck, Michael S. and Mary Stegmaier (2011). "Shocks and Oscillations: The political economy of Hungary”, Electoral Studies, 30, 462--467.

Mair, Peter (2012). “The Election in Context”, In: Gallagher, M., Marsh, M., How Ireland Voted 2011, The full story of Ireland's Earthquake Election (283--297). UK: Palgrave Macmillan.

Marsh, Michael (2000). "Candidate Centered but Party Wrapped: Campaigning in Ireland under STV”. In: Bowler, S., Grofman, B., (eds) Elections in Australia, Ireland and Malta under the single transferable vote (114-30). Michigan: University Press, Michigan. 
Marsh, Michael (2006). "Party identification in Ireland, An insecure anchor for a floating party system", Electoral Studies, 25:3, 489--508.

Marsh, Michael, Richard Sinnott, John Gary and Fiachra Kennedy (2008). The Irish Voter: The Nature of Electoral Competition in the Republic of Ireland. Manchester: Manchester University Press.

Marsh, Michael and James Tilley (2010). "The Attribution of Credit and Blame to Governments and its Impact on Vote Choice”, British Journal of Political Science 40:1, 115--134.

Marsh, Michael and Slava Mikhaylov (2012). "Economic Voting in a Crisis: the Irish election of 2011”, Electoral Studies (forthcoming).

Nadeau, Richard and Michael S. Lewis-Beck (2001). "National Economic Voting in US Presidential Elections", Journal of Politics, 63:1, 159--181.

Nannestad, Peter and Martin Paldam (1997). “The grievance asymmetry revisited: a micro study of economic voting in Denmark, 1986-92”, European Journal of Political Economy $13: 1,81-99$.

O’Leary, Eimear (2012). “General Election (Republic of Ireland) 2012”, Irish Political Studies 27:2, 326-340.

Peffley, Mark (1984). "The Voter as Juror, Attributing responsibility for economic conditions", Political Behavior, 6:3, 275 -- 294.

Powell, G. Bingham and Guy D. Whitten (1993). "A Cross-national Analysis of Economic Voting: taking account of the political context". American Journal of Political Science 37:2, 391--414. 
Soroka, Stuart N. (2006). "Good News and Bad News: Asymmetric Responses to Economic Information", Journal of Politics, 68:2, 372 -- 385.

Sanders, David (2003). "Party Identification, Economic Perceptions, and Voting in British General Elections, 1974-97”, Electoral Studies, 22, 239-263.

Tillman, Eric R. (2011). "Political Knowledge, the Global Economic Crisis, and Voting Behavior in the 2010 British General Election". Paper prepared for presentation at the Conference on European Responses to the Economic Crisis, April 7-8, 2011, Indiana University, Bloomington, IN.

Tufte, Edward R. (1978). Political Control of the Economy. Princeton: Princeton University Press.

Van der Brug, Wouter, Cees van der Eijk and Mark Franklin (2007). The Economy and the Vote, Economic Conditions and Elections in Fifteen Countries. Cambridge: Cambridge University Press.

Van der Brug, Wouter and Mark Franklin, et al. (2008)." One electorate or many? Differences in Party Preference Formation between New and Established European democracies", Electoral Studies, 27:4, 589--600.

Wlezien, Christoper, Mark Franklin and Daniel Twiggs (1997). „Economic Perceptions and Vote Choice: Disentangling the Endogeneity”, Political Behavior, 19:1, 7--17. 


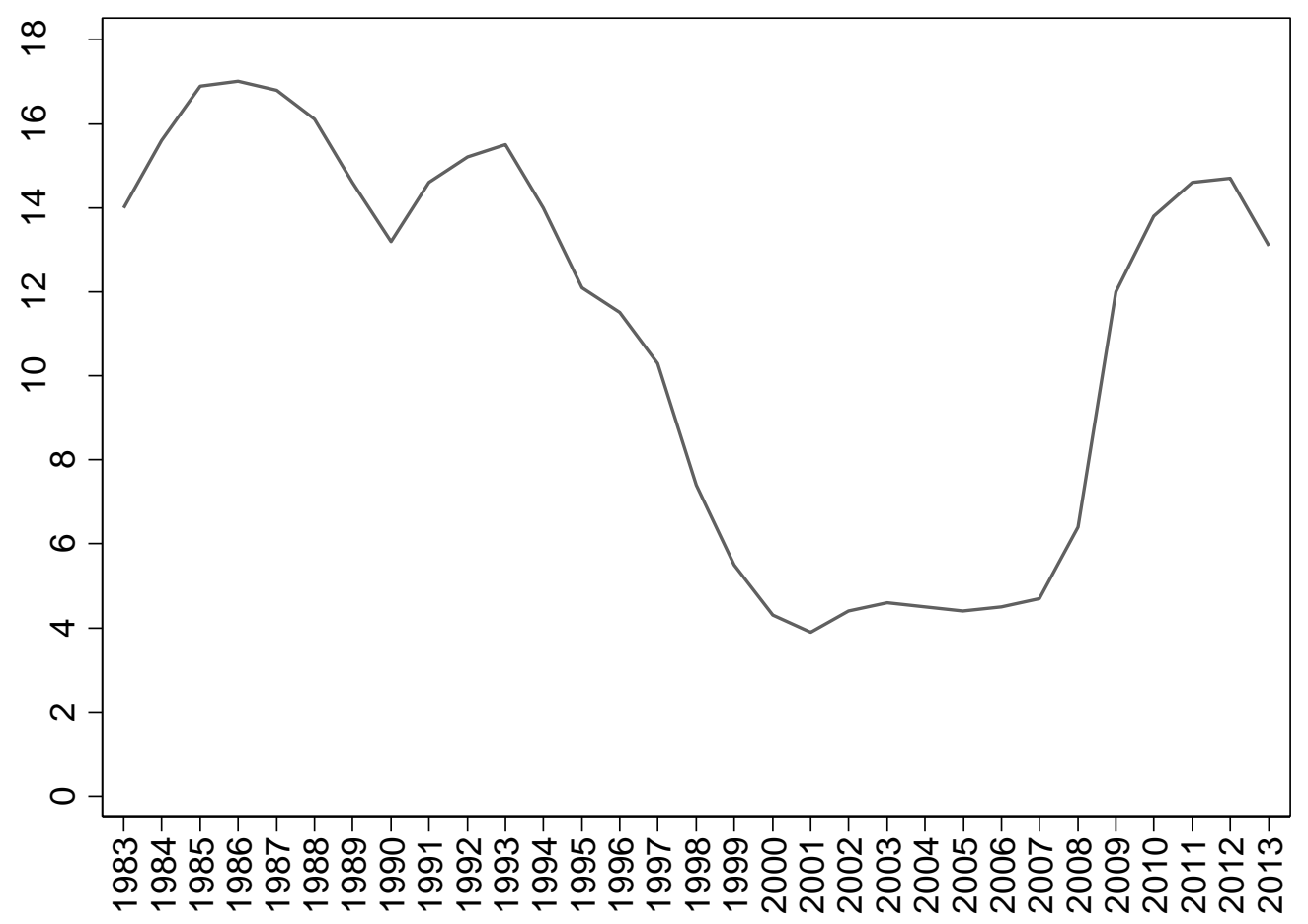

Figure 1. Standardised unemployment rate 1983-2013
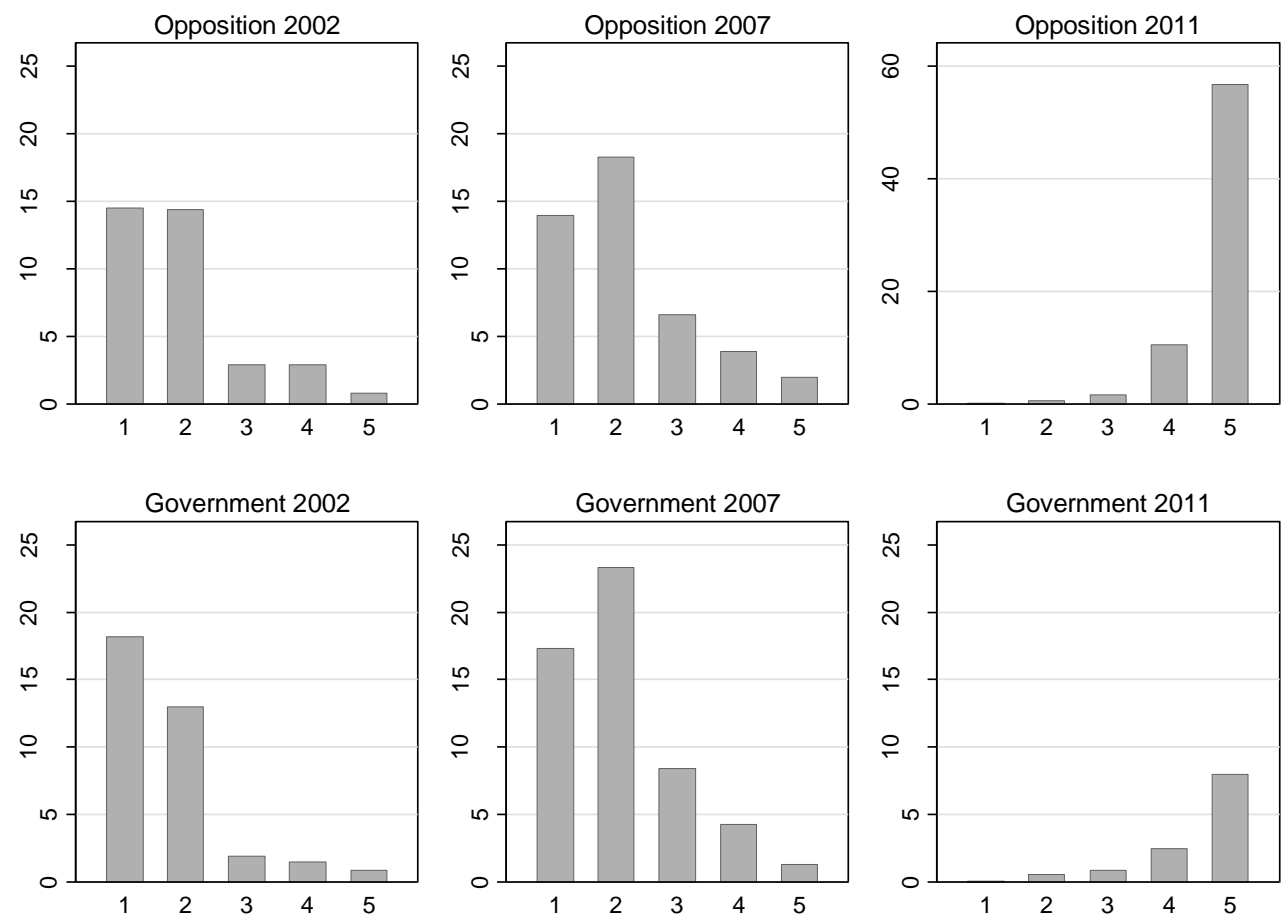
Figure 2. Economic voting: Retrospective evaluations of the economy. Notes: 1=Lot Better, 2=Little Better, 3=Same, 4=Little Worse, 5=Lot Worse.
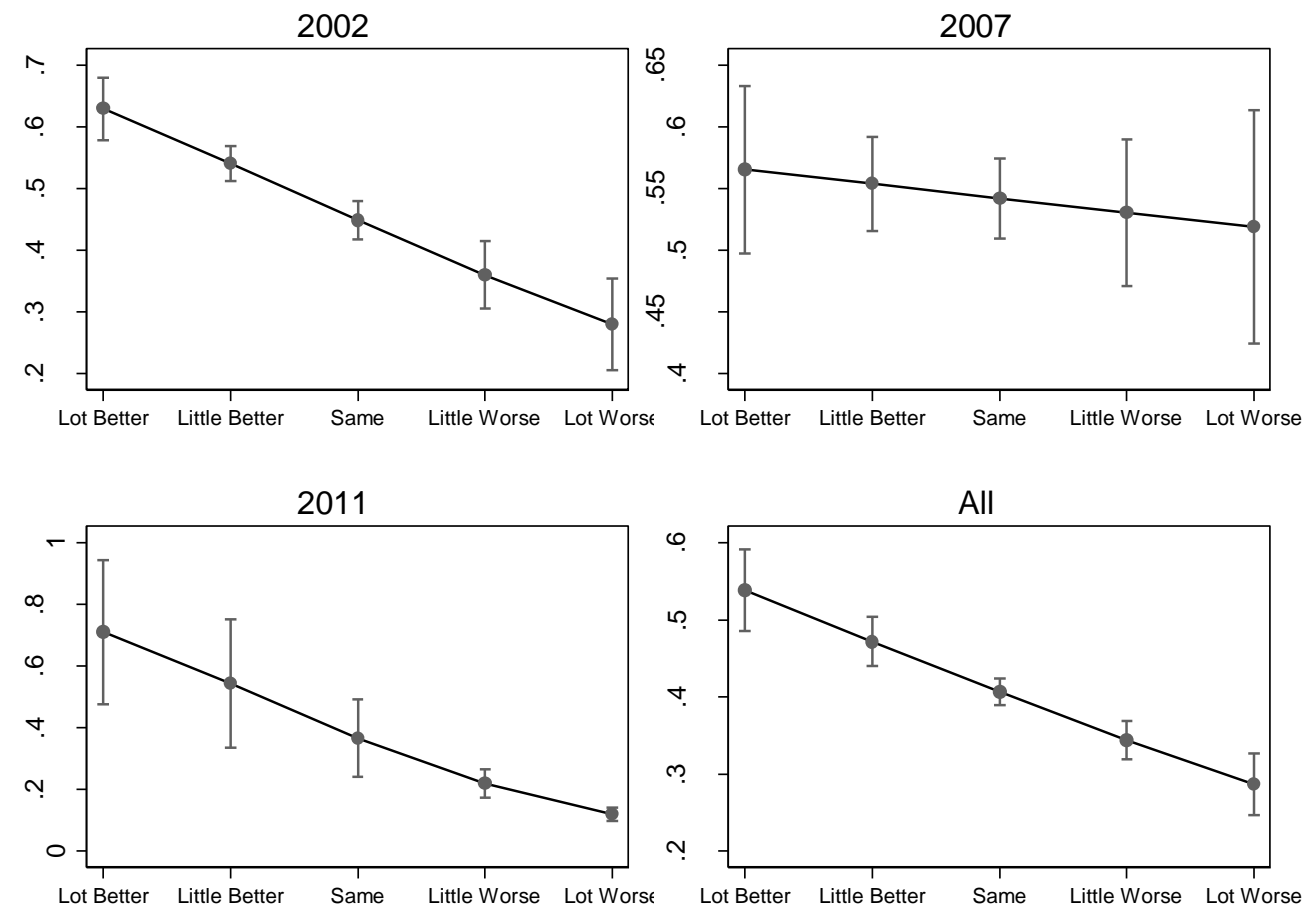

Figure 3. Change in predicted probability of government vote. Notes: Figures computed from models 1-4 in Table 1. 
Table 1. Economic evaluations over time

\begin{tabular}{|c|c|c|c|c|}
\hline & (1) & (2) & (3) & (4) \\
\hline & 2002 & 2007 & 2011 & Fixed \\
\hline \multirow[t]{2}{*}{ Evaluation } & $-1.47 * * *$ & -0.19 & $-2.88 * * *$ & $-1.07 * * *$ \\
\hline & $(0.278)$ & $(0.310)$ & $(0.622)$ & $(0.195)$ \\
\hline \multirow[t]{2}{*}{ Close } & $-1.43 * * *$ & 0.23 & $-2.19 * * *$ & $-0.99 * * *$ \\
\hline & $(0.308)$ & $(0.386)$ & $(0.560)$ & $(0.221)$ \\
\hline \multirow[t]{2}{*}{ Education } & $-1.23 * * *$ & 0.10 & $-0.99 * *$ & $-0.71 * * *$ \\
\hline & $(0.225)$ & $(0.256)$ & $(0.448)$ & $(0.156)$ \\
\hline \multirow[t]{2}{*}{ Income } & -0.01 & 0.40 & -0.10 & 0.15 \\
\hline & $(0.291)$ & $(0.277)$ & $(0.328)$ & $(0.167)$ \\
\hline \multirow[t]{2}{*}{ Age } & -0.23 & 0.50 & 0.43 & 0.13 \\
\hline & $(0.380)$ & $(0.444)$ & $(0.628)$ & $(0.257)$ \\
\hline Observations & 1,662 & 1,104 & 1,025 & 3,791 \\
\hline 11 & -1109 & -758 & -414 & -2312 \\
\hline chi2 & 86.0 & 4.50 & 50.7 & 535 \\
\hline$p$ & 0.00 & 0.48 & 0.00 & 0.00 \\
\hline
\end{tabular}

Dependent variable: vote for the government (recalled). Logistic regression. Standard errors in parentheses. Model 4 includes election year fixed effects (not displayed).

$$
* * * \mathrm{p}<0.01, * * \mathrm{p}<0.05, * \mathrm{p}<0.1
$$


Table 2. Retrospective unemployment

(1)

(2)

(3)

\begin{tabular}{|c|c|c|c|}
\hline & Pooled & Fixed & Random \\
\hline \multirow[t]{2}{*}{ Evaluation } & $-0.99 * * *$ & $-1.07 * * *$ & $-1.05 * * *$ \\
\hline & (0.194) & $(0.195)$ & $(0.195)$ \\
\hline \multirow[t]{2}{*}{ Close } & $-0.97 * * *$ & $-0.99 * * *$ & $-0.99 * * *$ \\
\hline & $(0.220)$ & $(0.221)$ & $(0.221)$ \\
\hline \multirow[t]{2}{*}{ Education } & $-0.71 * * *$ & $-0.71 * * *$ & $-0.71 * * *$ \\
\hline & $(0.156)$ & $(0.156)$ & $(0.156)$ \\
\hline \multirow[t]{2}{*}{ Income } & $0.30^{*}$ & 0.15 & 0.18 \\
\hline & $(0.162)$ & $(0.167)$ & $(0.168)$ \\
\hline \multirow[t]{2}{*}{ Age } & 0.21 & 0.13 & 0.15 \\
\hline & $(0.256)$ & $(0.257)$ & $(0.257)$ \\
\hline \multirow[t]{2}{*}{ Unemployment } & $-1.63 * * *$ & $-1.41 * * *$ & $-1.62 * * *$ \\
\hline & $(0.208)$ & $(0.216)$ & $(0.295)$ \\
\hline Observations & 3,791 & 3,791 & 3,791 \\
\hline 11 & -2319 & -2312 & -2315 \\
\hline chi2 & 520 & 535 & 179 \\
\hline $\mathrm{p}$ & 0 & 0 & 0 \\
\hline
\end{tabular}

Dependent variable: vote for government (recalled). Logistic regression. Standard errors in parentheses $* * * \mathrm{p}<0.01, * *$ $\mathrm{p}<0.05, * \mathrm{p}<0.1$ 
Table 3. Expected vote in 2011 under simulated conditions

\begin{tabular}{|c|c|c|}
\hline & $\begin{array}{c}\text { Government } \\
\text { vote would } \\
\text { be }\end{array}$ & $\begin{array}{l}\text { Opposition } \\
\text { vote would } \\
\text { be }\end{array}$ \\
\hline \multicolumn{3}{|l|}{ At maximum } \\
\hline $\begin{array}{l}\text { If all had negative evaluation of } \\
\text { economy }\end{array}$ & 8 & 92 \\
\hline If none close & 7 & 93 \\
\hline \multicolumn{3}{|l|}{ At minimum } \\
\hline $\begin{array}{l}\text { If none had negative evaluation of } \\
\text { economy }\end{array}$ & 50 & 50 \\
\hline If all close & 23 & 77 \\
\hline \multicolumn{3}{|c|}{$\begin{array}{l}\text { Actual vote was } 17 / 83 . \mathrm{N}=930 \text {. Table is predicted outcome if } \\
\text { variable at its maximum/minimum value and all others at their } \\
\text { mean value. Initial gives } 85 \% \text { correctly classified. Log likelihood } \\
\text { Full Model }-425.366 \text {. Prob > LR } 0.0000 \text {. }\end{array}$} \\
\hline
\end{tabular}

Table 4. Change in predicted probability of government vote

\begin{tabular}{lccll}
\hline & 2002 & 2011 & $\begin{array}{l}\text { Pooled with } \\
\text { country } \\
\text { fixed effects }\end{array}$ & $\begin{array}{l}\text { Pooled } \\
\text { (controlling } \\
\text { for macro } \\
\text { unemployment) }\end{array}$ \\
\hline Evaluation & -.349 & -.589 & -.252 & -.234 \\
Close & -.343 & -.312 & & \\
Education & -.298 & -135 & & \\
\hline
\end{tabular}

